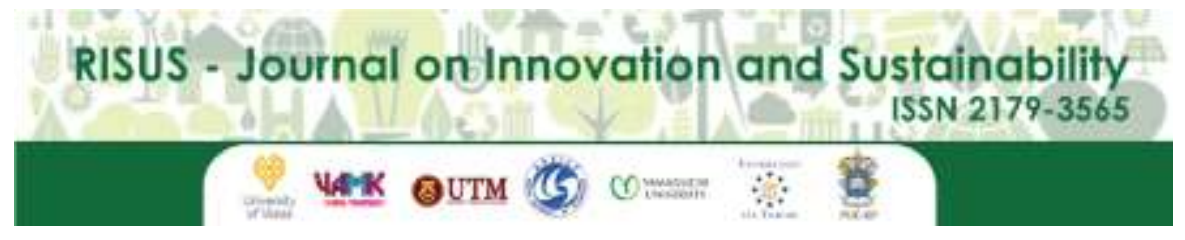

RISUS - Journal on Innovation and Sustainability volume 10, número 3 - 2019

ISSN: $2179-3565$

Editor Científico: Arnoldo José de Hoyos Guevara Editor Assistente: Luciano da Silva Ferreira Leite Avaliação: Melhores práticas editoriais da ANPAD

\title{
INTERNET OF THINGS (IOT) OPPORTUNITIES AND IMPACTS OF WELL- BEING ON CITIZENS AND SOCIETY
}

Internet das Coisas (IoT) Oportunidades e impactos do bem-estar dos cidadãos e da sociedade

Arnoldo José de Hoyos Guevara, José Luiz Alves da Silva
Pontificial University Catholic of São Paulo, São Paulo, Brazil
(E-mail: arnoldodehoyos@ yahoo.com.br, jl.alves@uol.com.br)

\begin{abstract}
The article presents a general scenario on the theme of Internet of Things - IoT, aiming to discuss the opportunities, the impacts and the associated risks, highlighting them under the sight of well-being in our lives and society in general. This paper deals with questions regarding accelerated and disruptive high-tech transformations, in order to be strategically prepared and to deal with challenges ahead. It is in the interest of all to know and anticipate the transformations that are underway and those that will be probable in the future, capturing the spirit of accelerated change that is around us, to prevent impacts, to draw personal strategies to seize opportunities and to avoid serious ruptures in our work and in our personal lives. The contribution for other studies is to allow ongoing discussions regarding the possible changes of behaviors coming from this new environment that will be made possible by the use of the IoT. Some of these behaviors are already on its way. Still, others are to be perceived and developed. This article presents, in the first topic, the new environment of the Fourth Industrial Revolution, where it is inserted the concept of IoT. It advances, in the second topic, with the discussion of the extension of the usage of the new technology, its impact and its applications. And it ends discussing the behavioral changes that the massive use of this application may bring us regarding well-being.
\end{abstract}

Key words: IoT-Internet of Things, Fourth Industrial Revolution, Well-being, Opportunities, Risks

\author{
ACEITO EM: 15/08/2019
}




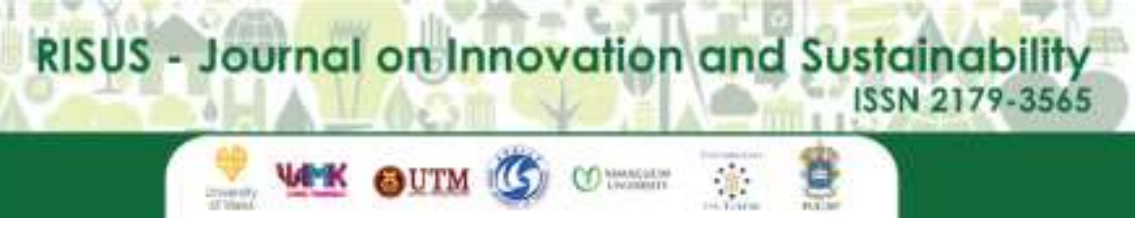

RISUS - Journal on Innovation and Sustainability volume 10, número 3 - 2019

ISSN: $2179-3565$

Editor Científico: Arnoldo José de Hoyos Guevara Editor Assistente: Luciano da Silva Ferreira Leite Avaliação: Melhores práticas editoriais da ANPAD

\title{
INTERNET DAS COISAS (IOT) OPORTUNIDADES E IMPACTOS DO BEM- ESTAR DOS CIDADÃOS E DA SOCIEDADE
}

Internet of things (iot) opportunities and impacts of well-being on citizens and society

\author{
Arnoldo José de Hoyos Guevara, José Luiz Alves da Silva \\ Pontificial University Catholic of São Paulo, São Paulo, Brazil \\ (E-mail: arnoldodehoyos@yahoo.com.br, jl.alves@uol.com.br)
}

Resumo: O artigo apresenta um cenário geral sobre o tema Internet das Coisas - IoT, com o objetivo de discutir as oportunidades, os impactos e os riscos associados, destacando-os à vista do bem-estar em nossas vidas e na sociedade em geral. Este artigo trata de questões relacionadas a transformações aceleradas e disruptivas de alta tecnologia, a fim de ser estrategicamente preparado e lidar com os desafios futuros. É do interesse de todos conhecer e antecipar as transformações que estão em andamento e as que serão prováveis no futuro, capturando o espírito de mudança acelerada que está ao nosso redor, para evitar impactos, desenhar estratégias pessoais para aproveitar oportunidades e evitar rupturas graves em nosso trabalho e em nossas vidas pessoais. A contribuição para outros estudos é permitir discussões contínuas sobre as possíveis mudanças de comportamentos provenientes desse novo ambiente que serão possíveis pelo uso da IoT. Alguns desses comportamentos já estão a caminho. Ainda assim, outros devem ser percebidos e desenvolvidos. Este artigo apresenta, no primeiro tópico, o novo ambiente da Quarta Revolução Industrial, onde está inserido o conceito de IoT. Avança, no segundo tópico, com a discussão sobre a extensão do uso da nova tecnologia, seu impacto e suas aplicações. E termina discutindo as mudanças comportamentais que o uso massivo desse aplicativo pode nos trazer em relação ao bem-estar.

Palavras-chave: Internet das coisas muito, quarta revolução industrial, bem-estar, oportunidades, riscos

\author{
ACEITO EM: 01/07/2019
}




\section{Introduction}

What are we dealing with? The perception of what is changing around us, in the light of new scientific advances and new technologies. Of which precepts, postures and attitudes may be changing without becoming aware and how it can change our reality or the way in which we perceive it. And how this may affect citizens and a society well-being. As matter of fact Jeremy Rifkin (Rifkin, 2011) already mentioned the great worldwide impact that we may expect on this XXI century as a result of Third Industrial Revolution through the merging of Internet Technologies and Renewable Energies.

Our powers of observation and the way in which we understand the changes underway, give us the power to adapt, to choose the paths to go and the decisions to be taken in our personal lives or in our professions. These are the opportunities, and several top universities like Oxford, MIT and Harvard are doing their work on that, as may be seen in the references.

All around the world in which we live, we come across social, political, economic, environmental and technological turmoil that change our relations and our scale of values. Even if we wanted to keep us unrelated to this, it is not possible. The changes around us can carry us together, we can perceive them and walk beside or can participate and take advantage of this new scenario, using or discovering new applications. These are the risks. In fact, we are moving fast into the direction of understanding that everything may be connected by means of sensors and the Internet. And as the person that created the term IoT, Kevin Ashton, mentioned already in 2009: IoT has the potential to change the world, just as the Internet did. Maybe even more so. ${ }^{1}$

We will discuss in this article about this scenario, called by many as the Fourth Industrial Revolution and pretentiously called by us, "The New Digital Age", only with the intention of putting on paper a general design, as an initial reference base, to comment, research, analyze, develop our own opinions and propose new visions.

\section{A look ahead to the challenge}

This is an exploratory analysis, using the vision of academics and researchers as Klaus Schwab, Alvin Toffler, Hamish McRae, Samuel Greengard, Andrew McAfee, Brynjolfsson, Frey, Osbornet and the researches of the authors regarding the disruptive technologies and changing behaviors of our society.

We are experiencing a world in constant integration. The famous researcher and entrepreneur Klaus Schwab, World Economic Forum founder and author of the book "The Fourth Industrial Revolution" (Schwab, 2016) presents us with a first vision in which shows the integration of Technological, Biological and Physical worlds. This is not just a forced and artificial joint, but the natural development of paths that started apart and slowly approached. Science, as it is known in its essence, searches for answers fully based on logic, in mathematics, in applied research and in the hypotheses proposed to explain the existing realities and build new theses. However, the barriers of technology advance and increasingly cover our relationships, our financial commitments, medicine, entertainment, production of consumer goods and services, shortening paths and allowing new behaviors. Society adapts, invents new fads or follow trends.

If you look at the last years of the last century, Hamish McRae (McRae, 1996) has pointed out the five forces that they were redesigning the world, focusing his look to the year 2020, now close to us:

- Technological advancement

\footnotetext{
${ }^{1}$ https://www.rfidjournal.com/articles/view?4986 
- The process of globalization

- $\quad$ The changing demographic structures

- The concern with the environment

- $\quad$ The impact of Government actions on society

All pointed forces remain present and the trends of technological advancement are indicated, without exception, in all Megatrends studies presented by the currently main consulting companies in the world. The wellbeing of citizens and society in general are completely dependent on these trends. We See, in intense fashion, the impacts relating to global conflict, focused on trade, immigration and religions surpass all possible frontiers.

In the case of Klaus Schwab, strengthening the concept of technological advancement, he presents an interconnection between technological skills, which decades ago displayed a certain degree of separation, but that are now very close (Schwab, 2016).

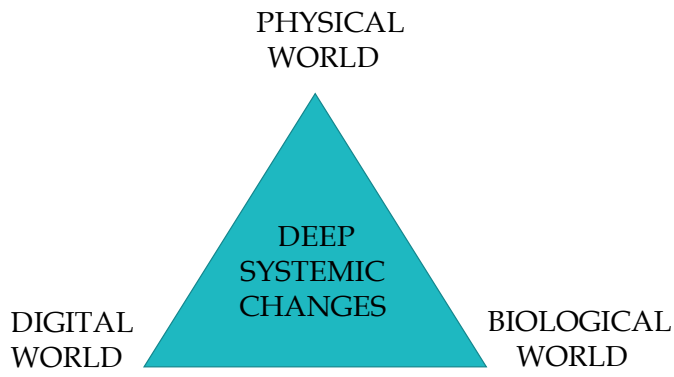

Figure 1. Fusion between Digital, Physical and Biological Worlds

The extension of this interconnection challenges us and shows us the composition of a new world, active, moving towards mergers between them and changing before our eyes.

Physical World: Technologies like autonomous vehicles, 3D and 4D printing, Advanced Robotics and new materials represent this category. This environment is more palpable, and we can see its connotations closer to us. Having a 3D printer at home and being able to "print" small tools, decorative or support item won't take long. And this technology changes the basic parameter of production assembling objects through agglutination of raw material rather than material loss on its traditional production. Replicas of human organs are being tested for simulations, studies and future transplants. In the case of autonomous vehicles already have several cases reported of tests on Amazon, Google, Tesla and Uber with, unfortunately, the first case of a fatal accident, occurred in this year.

Biological World: In this sector we include extraordinary genetic innovations, with sequencing, activations and editing genes recently made that was only possible by the computational increase. There is now the synthetic biology. Although there are serious ethical discussions involved, it has the ability to create custom bodies, applicable in agriculture, medicine or fuel, besides the possibility of specialized and personalized treatment for each individual. Let us not forget that in Brazil, we have advanced research at Embrapa, with creation of specialized seeds and adaptable to a variety of soils and climates, as well as resistant to various crop pests. In the future, considering the other developments, its scheduled the deployment of artificial memories in the brain of a human being. As well as considering the 3D printing combined with the editing of genes, will allow production, repair and regeneration of living tissue. This possibility is already being used to evaluate the creation of skin, bones, and muscle tissue in advanced medical centers of the planet.

Digital World: We indicate in this group, fundamental developments in progress, as the focus of this article, IoT-Internet of Things, the Blockchain, technology behind the cryptocurrency, the shared economy, the creation of 
new business models, social networks, with its astronomical dissemination of information and new digital platforms. Especially accentuated for the evolution of AI - Artificial Intelligence.

We emphasize the interrelationship with other categories and well-being in health, since the monitoring the human body, through sensors installed inside our body will allow the monitoring of symptoms, reactions, changes of heart rate, emergency calls or triggering the application of doses of drugs implanted under the skin. More from other interactions in the following topics.

The New Digital Age: Why do we frame here, supposedly, as we said, a new concept, calling this period "The New Digital Age"? Because the scope is much deeper than we have experienced before. As quoted by Klaus Schwab, "changes, in terms of size, speed and scope, are historical" (Schwab, The Fourth Industrial Revolution, pg. 12).

The second half of the 20th Century until now had an extraordinary development of technology, from a purely analog world to a digital world, more intuitive and with great interaction of people with machines, with computers and with the digital interfaces. In the history of the last 5,000 years, we're talking about only 50 years or $1 \%$ this period.

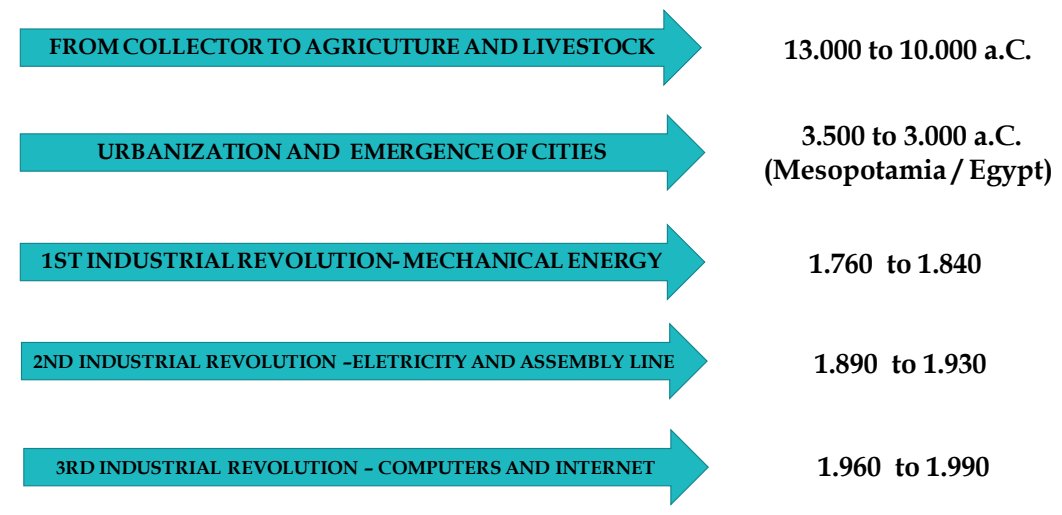

Figure 2. Up to The Third Industrial Revolution

From 1990 the working tools and interaction with the reality changed gigantically. The visionary Alvin Toffler, author of "The Third Wave" (Toffler,1980) and "Future Shock" (Toffler,1970) predicted, in the 70s and 80s, the so-called Knowledge Society, predicting a computer on the desk of every person. And emphasized the need for mastering knowledge, informing, in summary, that the illiterate of the 21 st century would not be the one who cannot read and write, but that you couldn't learn, unlearn and relearn. He warned that we would have the knowledge revolution. The main means of production would be the brain and not the brawn. And this new era would lead us to a world with new beliefs, attitudes, ethics and jobs (Toffler, 1980).

Trend Analysis on Digital Connectivity in Brazil: The technological innovation as a whole, the accelerated digitization, the internet and mobile telephony with their smartphones are fundamental tools of transformation developed from the 90s. Today we have more than 7 billion mobile devices worldwide and more than 200 million in Brazil, according to data from the Brazilian site Teleco.com ${ }^{2}$., Cepal and ITU. This gives a capacity of connectivity and access to information, immediately and digitally, and in an unprecedented manner in the history of humanity, allowing access from most of humanity to the bases of knowledge.

2 Teleco.com website: Statistics of July 2016. UIT, Wireless Intelligence, and Teleco.com. Available in: http://www.teleco.com.br/pais/celular.asp 
As an example of this reality in Brazil, we conducted a study of trends, with the Minitab tool, to evaluate the evolution of residences and connectivity of mobile devices in the country, considering data from the last 20 years and designing them for the next ten years (until 2028). We had the following results:
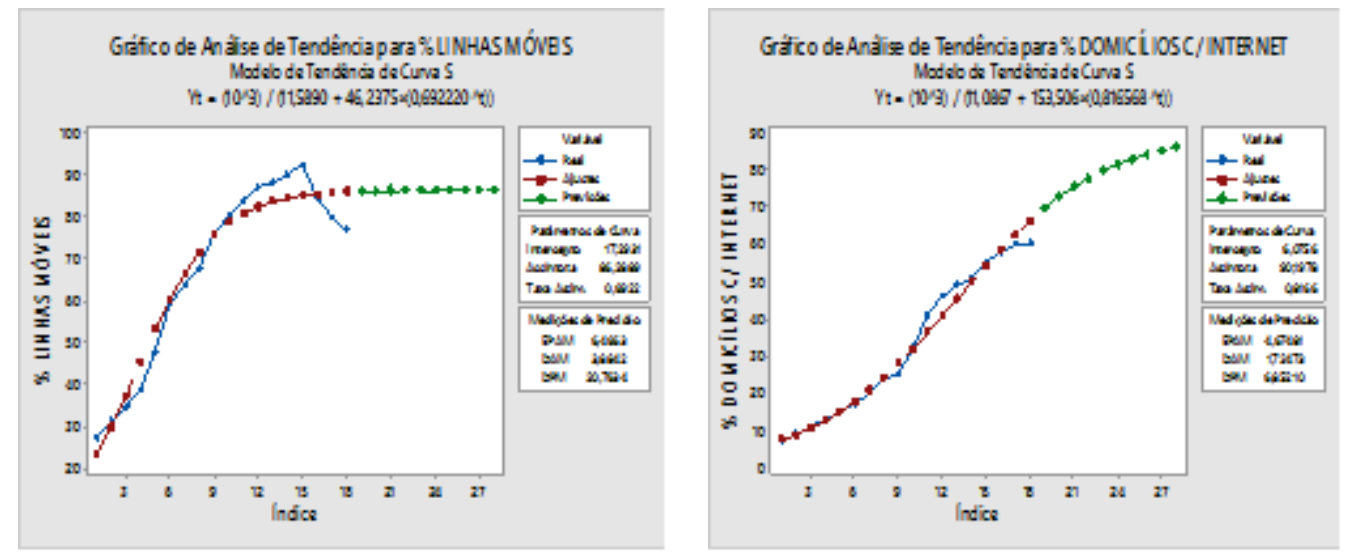

Figure 3 and 4. Trends of Digital Access in Brazil for 2028

We note that we have constant reductions in the fixed lines, access practically to the whole population of Brazil for mobile access and almost 80 million households with internet access. The basis for the digital society is given in our country.

Although a part of the world's population still does not have access to electricity or the Internet, in part of the globe, in the last 30 years we have prepared the basis for what you see now, with deep transformations in the way in which we communicate, act, work, study and have fun. In Africa, the continent with the highest global growth delay, displays accelerated digitization growth rates. This does not mean that we will make the best use, but that reality is present.

As shown by Schwab, the current changes were never experienced before. The Speed, Breadth, Depth and the Systemic Impact are immense, and these new technologies generate for themselves new solutions, exponentially. The modifications alter the way we live and can change who we are, the productive chains and entire economic systems (Schwab, 2016)

\section{Disruptive Technologies and New Trends}

The disruptive technologies are those capable of radically changing aspects of the economy, of society or of our personal lives. Open spaces and opportunities that would not be possible or that were not seen previously, change habits, needs and desires. Let's check some of them briefly, highlights in the world and that give us the context for evaluation of IoT, focus of this work.

Artificial Intelligence (AI): We speak here of one of the greatest advances of our time. The ability of cybernetic brains making decisions. Yes, that's the point. Don't we talk about the stratospheric processing capacity today already present in our businesses and our research centers. The novelty lies in the fact that the processing power increases in geometric scale and, because of this, the most advanced processors traveled paths that enable building sceneries and making decisions. Cognitive functions of a human being. You can see that we have some real indications in our world, as common examples that serve as samples of these advances. The uses are made in legal offices, to select and classify processes, in medical diagnoses and evaluation of dosage of medicines, on education and on accelerated learning, in the simulation of nature, events in process automation care and in decisions of financial investments. We are already observing how AI is becoming a disruptive kind of innovation 
that may soon influence every aspect of our lives (Kaplan, 2016). So, we may be really getting close to the end of what we know as The Human Era (Barret, 2013), and getting into the beginning of The Second Machine Age (Brynjolfsson, E., McAfee, A., 2016). Moreover, given the complexity involved on the way me may use AI a handbook like the one developed by Keith Frankish and William Ramsey (Franklin, K., Ramsey, W., 2014) is very well welcome.

These advances occurred with known developments. For example, the Deep Blue, computer mounted by IBM, which, in 1997, in London, won a match of six chess matches against world champion and grandmaster Garry Kasparov, getting the first image of the machine winning the man. Passed by 2011, the socalled Cognitive Computing feat of known Watson ${ }^{3}$, who won in a fierce dispute, in the most famous game of questions and answers of the USA, Jeopardy ${ }^{4}$ (CBS), the two most prominent previous champions in amount of questions answered and in awards, Ken Jennings and Brad Rutter. By 2015, 2016 and 2107, by the company AlphaGo, later acquired by Google, who beat world champions in the strategy game GO, the Chinese Fan Hui, South Korean Lee Sedol and the Chinese champion Ke Jie, respectively.

In this way, establish new behaviors or new diagnoses, answering scripting or advanced troubleshooting, without specific programming becomes a real possibility. The Machine Learning are learning with new situations and can make decisions of production, or medications for patients. Its evolution will be direct communication with other machines.

Internet of Things (IoT): The term Internet of things emerged based on the recognition that we are dealing with two different worlds, the digital world from the natural evolution of equipment and networks and the analogical world, unplugged, that already existed, and which would not require control and real time connection. It is formed by any of the equipment, element or supervised activities we can check in our society. The concept evolved once the needs and desires have expanded, as life became more dynamic and required greater control by people in general. What we present here is the possibility of interconnection of trillions of sensors around the world, passing data in real time to the digital world on the operation of equipment and things without direct connection to the Internet (using interfaces analog-to-digital), such as appliances, cameras, cars, houses, clothes, pipelines, toys and entire cities. We'll cover this in more detail on the second part of this article.

Big Data: We have to mention Big Data. If it isn't disruptive, once is continuity of processes developed for a long time, it is complementary to the two technologies mentioned earlier. We can consider these as a basic tripod for the analysis of behavior and social scenarios drawing, today called analytical techniques or "analytics". The vision of a world controlled by the information is so big that surprising what we can accomplish today. All our behaviors feed huge databases, supplied to the extent we do purchase operations, watched movies, travel, we browsed the Internet, fill out surveys or registers or communicate with others. Previously known as Datawarehouse's, these tools worked with Structured Data, existing in pre-formatted databases in companies. Today the use of the name Big Data is required, because the new databases are powered by Unstructured Data from Social networks, Electronic media and pure Internet navigation. Thomas Davenport said that the most important thing is not to be impressed by the volume of data but rather to analyze to convert them into knowledge, innovation and value (Davenport, 2014). This information becomes Knowledge, enabling the decision making. IoT, Big Data and Artificial Intelligence will be the basis for Decision Makers or Automatized Actions in Smart Cities and Autonomous Cars, among other applications.

3 Gizmodo website: Watson. Available in: http://Gizmodo.Uol.Com.Br/Computador-Da-Ibm-Vence-De-Lavada-DoisCerebros-Humanos-Em-Jogo-De-Conhecimentos-Gerais/

${ }^{4}$ Tech Republic.com website: Watson. Available in: https://Www.Techrepublic.Com/Article/Ibm-Watson-The-Inside-Story-OfHow-The-Jeopardy-Winning-Supercomputer-Was-Born-And-What-It-Wants-To-Do-Next/ 
Blockchain: Blockchain is a technology seen today as one of the greatest technological breaks. It is regarded as the new Digital Notary, able to record transactions of any kind, with security and traceability. It is the technology created as the basis for the cryptocurrencies, as the Bitcoin, the most popular of this universe. It was developed by the programmer of pseudonym Satoshi Nakamoto, in 2008, putting the program code available directly on the Internet. Ensures the private control and various applications such as the cataloguing of works of art, weapons or transactions with diamonds, allow and certify Authenticity and Registration of trade. There are Governments with early works for tax collection with Blockchain technology and financial banks working with end-to-end transactions. And even, in drafting laws to ban the use of cryptocurrencies in their territories, for the risk of loss of control it can represent. But Blockchain is going much more ahead and may become a disruptive computing paradigm as mentioned by M. Swan (Swan, 2015).

Quantum Computation: This area of science promises to revolutionize the future of humanity, ensuring that we will have the possibility of creating processors with higher current capabilities in speed and processing power. This is because the process of development of microelectronics has its limitations. The capacity of a traditional computer chip double every 18 months, was broken recently, indicating the limits of this border. The creation of quantum processors would lead the process of performing calculations for a kind of parallel processing, in which multiple possibilities would be calculated at the same time or multiple scenarios would be handled together. However, these processors work in extremely low temperatures, bringing great challenges for your swift implementation. The attention here is because a superior capacity to process would influence all other trends discussed up to here, the performance of each one of them. And could create scenarios in which the Artificial Intelligence could reach your peak, enabling highly complex decisions.

Nanotechnology: One of the most able developments of our times are those applied by Nanotechnology. Machinery, chemical systems, medical and pharmaceutical medicines with cell dimension, acting and performing microscopic changes, either within the human body, in agriculture or in the physical world. Some of the experiments already running, produce molecular structures working in toxic environments, which invade cells, acting on evil difficult or almost impossible to be treated with high precision, with fewer side effects. Here is one of the links between the world of technology and biology, because the existing potential extrapolate traditional treatments. Pharmaceutical nanotechnology, for example, is used for the treatment, diagnosis, monitoring and control of biological systems and has recently been named "Nanomedicine" by the National Institute of Health in the United States (Moghimi et al, 2005). In Brazil, we have the example of the pharmaceutical laboratory at State of São Paulo, which is using this technology to manufacture a pill, still in approval by ANVISA, with the antimalarial artemether, a semisynthetic substance encapsulated in microscopic doses and very intense, to get the highest efficiency and be less aggressive for the human organism.

New Materials: In the industry we have available the development of new materials that promise to revolutionize the way of producing and transporting energy. Some of these materials are lighter, stronger and recyclable, and allow self-repair and self-cleaning applications, with resilience and return to their original forms or transducers that turn pressure into energy, a huge advantage. Others, as plastics, allow reuse parts of products that are difficult to recycle, like those used in cell phones or parts for space industry, for example. One of the greatest exponents of the moment is Graphene, one of the crystalline forms of carbon, as well as diamond or graphite. This material is considered so revolutionary as that silicon, essential to the development of semiconductors and the evolution of computers. Of high quality, is 200 times stronger than steel, lightweight, almost transparent, much thinner than a hair, an excellent conductor of heat and electricity. Is one of the strongest materials ever found, but also extremely expensive. The combination of extraordinary properties and surprising ease of isolation allowed an explosion in research about Graphene and their use in recent years. The Nobel Prize in physics of 2010 was awarded to Andre Geim and Konstantin Novoselov of the University of Manchester by innovative experiences regarding this material. 


\section{IoT: Internet of Things}

When we talk about the fact that we can connect things to the Internet, we are talking about our ability to receive information and make decisions from the recognition of reality. And this represents a cultural and behavioral change without dimension. When it comes to personal well-being, we become "owners" of decision making, which may be under our control. Or we can "delegate" this control to third parties or to the network that will have the power to take decisions on our place. Seems a simple situation, but it is not. In this reality we can be carried by currents or interact with it consciously. The researcher Samuel Greengard tell us that IoT is at the epicenter of one innovation shock wave that it is just getting started and it is in the way between the innovator and early adopter phases. It will someday serve as the practical framework for life and for business (Greengard, 2015).

All digital equipment that we know as smartphones, laptops, personal computers, smart-tv's, cameras, and other resources are already connected to the digital world. The world of "things not yet digital" can be connected to the network by geolocation features or interfaces that can send information. For example, RFID adhesives (radio frequency identification) for the location of a container or objects of any size inside of them. Or by monitoring mobile or satellite communication with remote sensors in aqueducts, oil pipelines, POSs (Point of Sail), cars, planes or drones. This allows a capacity of above-normal control as to the physical world that we know today and in which we live.

Combining this new connectivity to a high capacity of processing we have the opportunity to automatize processes until now unthinkable. And, main point of view, change the way how to take decision, with the possibility of automatic decisions. At the end, changing our mindset about how to live or manage our lives.

Since control the dose of a medicine inserted under the skin and monitored by IoT, remotely trigger a call and send an ambulance for heart attack, without human intervention, control traffic lights automatically at any time of day, monitor constantly the increase of cholesterol in the human body, supply our refrigerators and layoffs by the supermarket without prior request, to trigger the lights in our house and an oven to heat up our food before we get home.

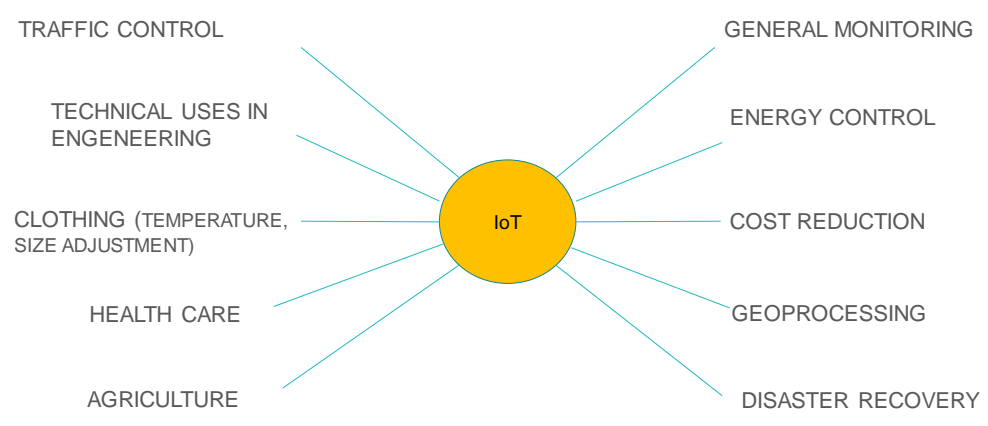

Figure 5 - IoT applications

Geoprocessing and Smart Cities: One of the most fantastic tools available to dealings of the well-being and quality of life, if well used the geo-processing and geo-location. It is the possibility of using the knowledge of the society in which we are living. Opportunities for improvement of public administration are immense. Since sensing works for garbage collection, monitoring of slopes and risks of collapse in rains, sewer, water leaks through the security assessment in areas of risk for displacement of police forces, automatic sensing of the population present in certain neighborhoods to installation of health centers, schools and police stations, offset daily assessment of people and their interests. The use of APPs (applications) on mobile phones already allow currently these automatic withdrawals. 
The process itself, allows the accelerated evolution of the so-called Smart Cities. We speak about cities that have intelligence to decide about the movement of people, public facilities, autonomous vehicles, garbage collection, public transport, sustainability, control flow and use of water, energy, telecommunications and fuels. Without the IoT, we will not be able for this implementation. The geolocation is an essential tool in this subject, allowing the scope of the entire physical area and/or of all its inhabitants. Automatic interaction with "public facilities", its parks, its educational institutions, its citizens, their vehicles, shops and services, possibly favor the health demands, safety and well-being in a way never have seen before.

Smart Homes: One of the biggest behavioral change that have already begun and directly impacts our lives is our condition to "control" remotely the environment in which we live, interacting automatically with the objects around us. Already are common and possible the Ip (Internet Protocol) cameras, connected to the Internet for remote monitoring from our homes or monitoring of babies, our elderly relatives or our PETs. With sensors placed around the House, we can control the lighting, fire alarms or emergency care without even being present. Interact with our environment allows you to plan to purchase foods that end up in our homes, with automatic requests to supermarkets. Behavioral changes. For this monitoring, sensors of IoT would need to be in the fridge, in pots or boxes of food.

Avatars began to invade our familiar surroundings in all its possibilities, since applications like Google Play, which aids in the automatic search of anything we want like electronic helpers such as the smart-TVs, seeking to turn into platform only for images, sounds and Internet access. In other words, we have new "interfaces" that will facilitate the integration of the physical and technological worlds.

Health Monitoring: The possibilities are now practically limitless regarding health monitoring via sensors of IoT, stuck in our bodies or the pills we take. We already have the basic conditions for training and races that track our heartbeat or the burning of calories. However, we can easily to inject body sensors that measure our levels of adrenaline and insulin, for example, ensuring that medicines implemented under the skin can release controlled doses. Pills for schizophrenia are being tested in the USA for this purpose, for example.

Of course, this new world will not bring only advantages. With evolution, we have and we're going to have high risks associated with Cyber-attacks, exposition and control about our behaviors. The control over the citizen's life, your likes and desires, your displacement, the knowledge of their habits and your entertainment should not be conducted steadily and indiscriminately. It's a risk and requires extreme care. There are studies in some countries, projecting controls of "score" for remarkable citizens, for which would offer greater access to housing or access to credit, according a behavior considered appropriate by the standards set. The IoT would enter here with millions of cameras, sensors and APPs installation, which could provide instantly information about ongoing actions. As has been highlighted before, is not technology that presents a risk, but the way which we make use of that.

This extraordinary knowledge is also available to be exploited by hackers or crackers that use technological failures as livelihood and profit. In this way, products that needs to be developed, will need provide reliability and safety, that should be created together and provided as a basic requirement of their supply. 


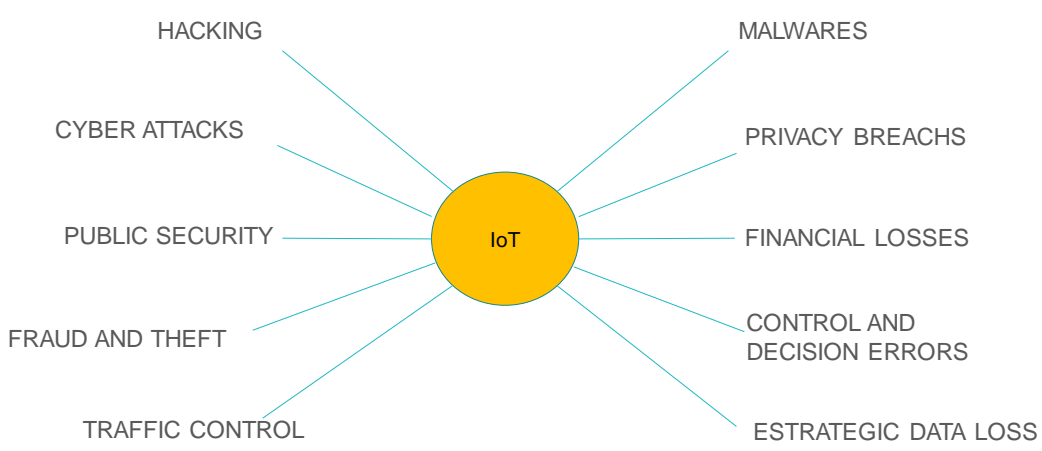

Figure 6 - IoT Risks

\section{Results: Behavior Changes}

Employability: In the current process of digital transformation, it is estimated that around 2025, until 47\% of jobs in the USA, related to occupations with high automation potential, should disappear (Frey, Osbornet, 2013). This means that, with new aspirations, there will be opportunities to create jobs and get back to higher-value activities. We are able to construct them by knowledge of the environment in which we operate. So, with advanced connection will enable new possibilities of interaction with our jobs. And the IoT will enable remote workers monitor, as if they were present at the regular jobs and also will allow control of resources remotely. We will have "Employability" and no more "Formal Jobs". Data scientists, for example, already are a new career in course and currently are not required to be present to act and they can offer your work for different customers.

New Business Models: The structures that have evolved in recent years, with new concepts, challenged established views and ways to realize the contact with customers and consumers. The intermediations, considered to be part of the negotiating game, either by the infrastructure or by existing expertise, have been overcome. We have new business around the world like AirBnb, Amazon, Uber, Netflix or Brazilian companies like 99Taxi, Nubank and Ifood. Al of them need of internet and mobile devices, working as an IoT components.

Direct contact with the customers became more effective and have been forcefully changed. Today, ContactCenters have more complete with various communication alternatives, such as chatbots, IVRs, AI, voice, e-mail, regular chats, collaboration with support of an attendant image online, or the presence of avatars, created digitally to accomplish this interaction, via voice or with the image on screen.

The Shared Economy has been the subject of opportunities that use these applications to connect consumers directly to the suppliers, without shops or promotions contrived. The APPs and sensors locate the client automatically and offer him the best experience or solutions of locomotion, as we see today, in home delivery, taxi ordering, orders monitoring, movement in the cities with Waze or Google, for example. The called Fintech's, Aggrotech's or Insurtech's, financial, agribusiness and insurance segments respectively, are using IoT to facilitate their business and increased efficiency. We have had 36\% of growing of Fintechs companies at Brazil in 2017, for example. Each of these areas requires sensors installed or mobile devices such as "location providers", for carried out their tasks.

New Behaviors: IoT sensors will spread across our clothes, during exercise, in our medical or measure the level of performance of the services consumed, automatic reading of electricity consumption, the water used, or the calories consumed, bringing us to willingness to change our decisions and not rely on what is reported by the media or by our suppliers.

The developments also reached the applications that can read the same data directly, what have done before only by companies. Apps in mobile phones, chatbots (conversations with robots), avatars and robots mounted based 
on AI (via automated software systems), evaluate the available data and inform directly the user of his situation. Soon, medical applications will make diagnoses based on sensors installed in your body, without the direct participation of a doctor. It is expected that the first robotic pharmacist, would be available in 2025 .

The buying process itself is changing. In shops, grocery stores or arenas are offered products by simple passage or presence of the consumer, monitored by your mobile device, by your clothes or your watches, as elements of IoT.

The buying process by proximity with NFC (Near Field Communication), boarding with read code QRC (Quick Response Code), monitoring objects in stores, activation of cars by proximity, passing through tolls for vehicles on roads automatically, automatic reading of shows or programs congresses are a reality of IoT and AI.

The incorporation of new practices will lead to changes in behavior and consumer profile, as well as flexibility in the way we introduce ourselves in front of our customers, family and friends, in dress and communicate. Will we monitor each step of them by IoT and take decisions from this? Today we monitor the purchases we make, as well we are monitored by security centers that assess our shopping patterns to avoid fraud. Our personal task and professional is get necessary consciousness and decide how we can adapt.

\section{Conclusion}

The new technologies are undoubtedly shaping the 21st century. Schwab says the Fourth Industrial Revolution is a new chapter of human development (Schwab, 2018). IoT is the open door to be connected with this new digital world. The cell phone itself is the largest "IoT personal sensor" already available. Consider the evolutions allowed by several developments cited here for IoT and other technologies that complement its use and application, since it is not possible to talk of IoT separately.

With digitized access extrapolated to a significant number of people in the world, abundant access to information, mobility, the facilities brought by social networks and the constant connectivity, we have new opportunities and possibilities opened for the exploitation of society in general. At work, we can do our tasks remotely, send our productions over the network or access solutions that are available worldwide.

Ancient and visionaries books of the past have explored these possibilities George Orwell, in your fiction book "1984", which created the Big Brother figure, feared to be controlled by pain, by a culture contained and with fully targeted information. Aldous Huxley, in your fiction book "Brave New World", understood that we would be flooded with an endless amount of information, pleasure and controlled by a trivial culture, based in ordinary situations and distractions. In this way, we reached a point where new generations of consumers are undergoing a change in which possession is not the most important, but rather the use and experimentation. The natural status of ownership comes to be disputed in some cases.

In addition, we will pass through a discussion on the future worker, with changes in current professions and the emergence of new occupations, both formal and informal. We will carry the discussion on lasting careers in midsize and large enterprises or on the ability of employability focuses on knowledge and skill of each professional. When, what will matter will be the experiences and achievements accumulated and that will be employed and offered in different environments throughout their lives.

Staying connected and aware of the changes, participating in them becomes our best alternative and our main demand, if we want to be part of this transformation. Learning to use the technology and its potential will put us in a different situation. Evaluating the social impacts of change, proposing viable alternatives in our designs to include people and professionals and avoiding the chaos of transformation is an additional challenge of society, enterprises 
and a requirement of each one of us. Information, knowledge, choice and adaptability are the key weapons of this participation.

Regarding our well-being, there will be no choice but to learn more and more about the world in which we operate, where new technologies are leading us, about what can be our alternatives and how can we collaborate with society. In other words, in the opinion of these authors, the human being in the new digital society, need to carry out your role in an integrated manner, conscious and participatory. The directions here explored, in particular to the extraordinary advancement of technology and the economy. The use of durable, formal education, knowledge sharing and integration of less able will have to be a common goal of society.

These are the challenges that will require of us, academics and professionals from all areas, adaptability and constant efforts to track and discover new paths, behaviors and opportunities in these times of IoT, of the Fourth Industrial Revolution and The New Digital Age, that may help fostering a more Humane Development and the Global Well-Being, as recommended by Klaus Schwab (Schwab, 2018).

\section{References}

[1] Barrat, J. Artificial Intelligence and the End of The Human Era [M]. Thomas Dunne Books, 2013

[2] Brynjolfsson, W., McAfee, A. The Second Machine Age[M]. W. W. Norton, 2016

[3] Davenport, T. Big Data at work: dispelling the myths, uncovering the opportunities [M]. Harvard Business Review Press, 2014

[4] Franklin, K., Ramsey, W. The Cambridge Handbook on Artificial Intelligence [M], Cambridge Univ. Press, 2014.

[5] Frey, C. B., Osbornet, M. The future of employment: How Susceptible Are Jobs to Computerization? [J]. Technological Forecasting and Social Change, Oxford Martin School University UK, 2013,114(1):254-280

[6] Greengard, S. The Internet of Things [M], MIT Press Essential Knowledge Series, 2015

[7] Kaplan, J. Artificial Intelligence: What everybody needs to know [M]. Oxford University Press, 2016

[8] Mcrae, H. The World in 2020 Power, Culture and Prosperity [M], Harvard Business Review, 1996 
[9] Moghimi, S.M., Hunter, A.C., Murray, J. C. Nanomedicine: Current Status and Future Prospects [J]. The Faseb J., 2005,19(1):311-330.

[10] Rifkin, J. The Third Industrial Revolution: How lateral power is transforming energy, the economy and the world [M]. Palgrave McMillian, 2011

[11] Schwab, K. The 4th Industrial Revolution [M], WEF, 2016

[12] Schwab, K. Shaping the Fourth Industrial Revolution [M], WEF, 2018

[13] Swan, M. Blockchain: Blueprint for a New Economy [M], O’Reilly Media, 2015.

[14] Toffler, A. Future Shock [M], Bantam Books, 1970.

[15] Toffler, A. The Third Wave [M], Bantam Books, 1980. 